by Joel C. Gill*

\title{
Geology and the Sustainable Development Goals
}

\author{
Geology for Global Development, London, UK; *Corresponding author, E-mail: joel@gfgd.org
}

(Received: October 1, 2015; Revised accepted: February 19, 2016)

http://dx.doi.org/10.18814/epiiugs/2017/v40i1/017010

This paper presents an overview and visualisation of the role of geology in the Sustainable Development Goals (SDGs). These internationally-agreed goals aim to eradicate global poverty, end unsustainable consumption patterns, and facilitate sustained and inclusive growth, social development, and environmental protection. Through a matrix visualisation, this paper presents a synthesis that relates the 17 agreed SDGs to 11 key aspects of geology. Aspects considered are agrogeology, climate change, energy, engineering geology, geohazards, geoheritage and geotourism, hydrogeology and contaminant geology, mineral and rock resources, geoeducation, geological capacity building, and a miscellaneous category. The matrix demonstrates that geologists have a role in achieving all 17 of the SDGs. Three topics relating to improved engagement by geologists with international development are then highlighted for discussion. These are the development of supporting skills in education, improving transnational research collaborations, and ensuring respectful capacity building initiatives. This synthesis can help mobilise the broader geology community to engage in the SDGs, allowing those working on specific aspects of geology to consider their work in the context of sustainable development. The contribution that geologists can make to sustainable development is also demonstrated to other relevant disciplines, and development policy and practitioner communities.

\section{Introduction}

In September 2015 the Sustainable Development Goals (United Nations, 2015a) were formally adopted by member states of the United Nations, building on the Millennium Development Goals (Millennium Project, 2006). The Sustainable Development Goals (SDGs) are an ambitious set of 17 goals and 169 targets. Their stated aims are to eradicate global poverty, end unsustainable consumption patterns and facilitate sustained and inclusive economic growth, social development and environmental protection (United Nations, 2015a) over a 15-year timeframe (2015-2030). Achieving the SDGs by 2030 will require many communities and sectors to engage, including the geological sciences (Lubchenco et al., 2015). Many of the themes within the SDGs are pertinent to geological research and practice. The geol- ogy community, therefore, should be ready and equipped to take a leading role in promoting and facilitating responsible Earth stewardship, for the public good and global development.

Geology students, educators, researchers, industry professionals, public servants and policymakers all have a role to play in helping to achieve the SDGs, ensuring sustainable and equitable foundations for future global development. Their knowledge of the Earth's structure, the materials it is made of, and the processes by which it is constantly being shaped can be used to inform many important areas of sustainable development, as illustrated in Figure 1. Here 12 ways by which geology contributes to sustainable development are visualised. Each of these broad groups includes a number of practical applications to responsible Earth stewardship. Examples include:

- Access to clean water and safe sanitation (e.g., identifying groundwater resources; preventing contamination).

- Food security and agrogeology (e.g., using local rock and mineral materials to improve soil fertility).

- Disaster risk reduction (e.g., understanding the physical science underlying the generation of landslides, earthquakes and volcanic eruptions; assessing exposure through producing hazard maps; reducing vulnerability through geoeducation initiatives).

- Energy supply and management (e.g., identifying the potential of a geothermal energy supply; understanding hydrocarbon potential and safe extraction of resources).

- Improved infrastructure and access to basic services (e.g., geomorphological mapping for road construction; characterising rock masses prior to dam construction).

- Environmental and biodiversity management and conservation (e.g., geochemical monitoring of pollution migration through an ecosystem).

Geological research, monitoring, innovation, and engineering in all of the aspects described within Figure 1 can drive widespread improvements to wellbeing and quality of life. The societal relevance of geology has long been recognised, with many members of the geology community committed to the practical application of our discipline to address challenges of global hardship, inequality, and vulnerability (Stow and Laming, 1991; Cordani, 2000; Mora, 2013). Organisations such as the Association of Geoscientists for International Development (AGID) have helped promote the vital role of geology in socioeconomic development for over 40 years (AGID, 2016). The British Geological Survey (BGS) also has a long history of engagement with the UK Department for International Development, formerly the Overseas Development Agency (BGS, 2016). More recent initiatives include the International Union of Geological Sciences (IUGS) initia- 


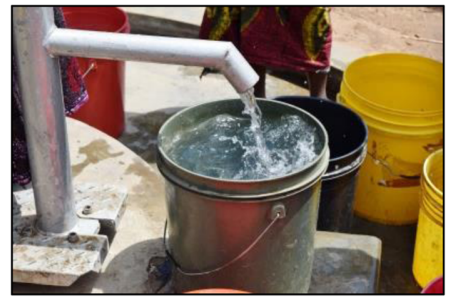

Access and Management of Clean Water and Sanitation

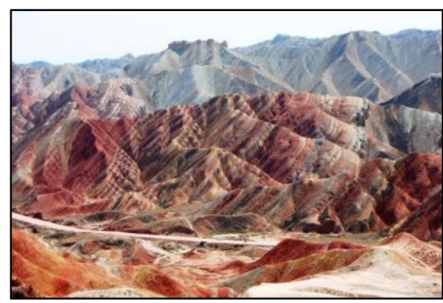

Geotourism

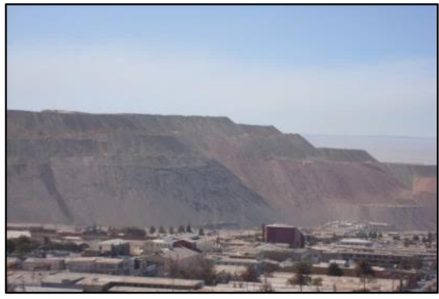

Natural Resources and Mining

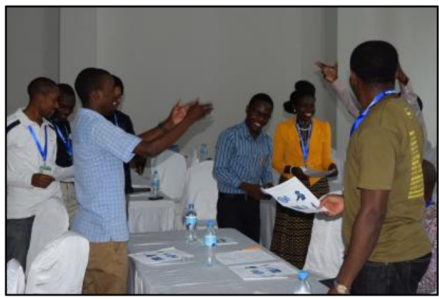

Higher Education and Professional Development

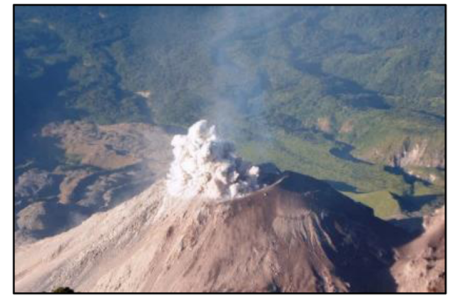

Geohazard Management and Disaster Risk Reduction

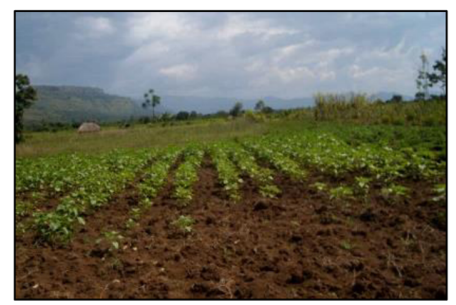

Strengthening Agriculture (Agrogeology) and Food Security

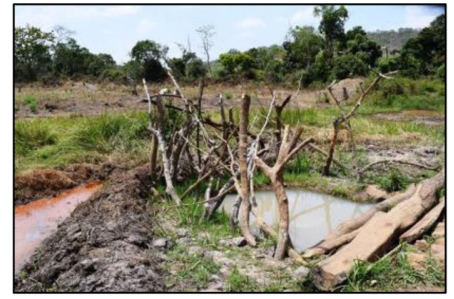

Environmental Management

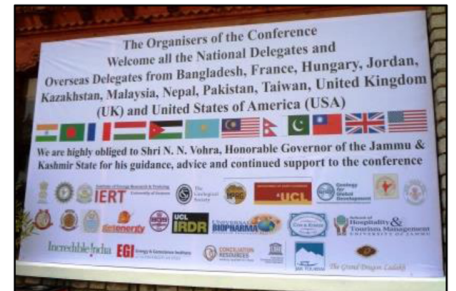

Geodiplomacy

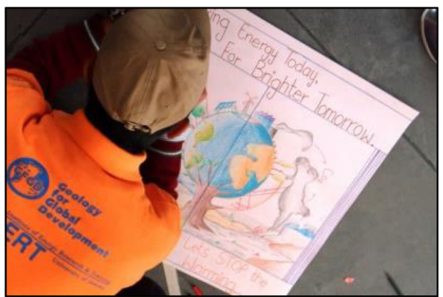

Energy Supply and Conservation, and Climate Change

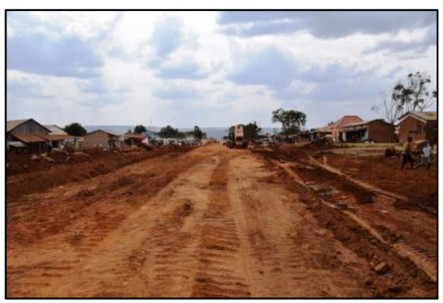

Engineering Geology for Infrastructure Development

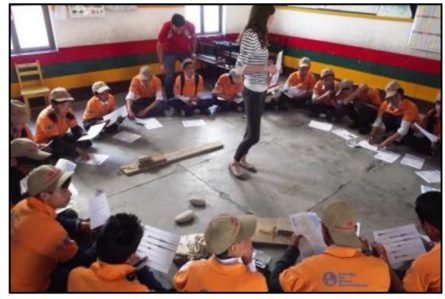

Geoeducation

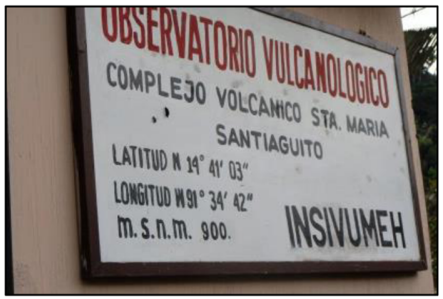

Supporting

National Institutions

Figure 1. Twelve interactions between geology and international development, a core component of sustainable development.

tive 'Resourcing Future Generations' (Lambert et al., 2013) and the launch of Geology for Global Development (GfGD) in the UK in 2011 (Gill, 2012). This commendable record should not result in complacency however, or a belief that effectively engaging with sustainable development is the responsibility of a few. If geologists are to effectively serve society over the coming decades, we should all (i) evaluate the role that we can play in eradicating global poverty and facilitating sustainable development, and (ii) recognise the importance of communicating with policy makers, administrators and other disciplines engaged in facilitating development.

\section{Current development challenges}

Since the Millennium Development Goals were agreed in 2000, there has been welcome progress in tackling poverty. Globally, the number of extreme poor has fallen by over $50 \%$, there are almost half as many out-of-school children of primary school age, and the maternal mortality ratio has reduced by $36 \%$ when contrasting figures from 2000 and 2015 (United Nations, 2015b). Access to an improved drinking water source is noted to have increased from $76 \%$ of the global population in 1990 to $91 \%$ of the global population in 2015 , with $73 \%$ of this increase being through piped water to premises (United Nations, 2015b). These, and other aspects of progress, should be celebrated and the reasons contributing to success studied in detail to better understand how further improvements can be made.

Progress, however, has been incredibly uneven, with extreme poverty persisting in some parts of the world. Example statistics from the United Nations (2015b) show that, with respect to the population of sub-Saharan Africa:

- $70 \%$ are not using improved sanitation facilities.

- $32 \%$ lack access to an improved water source.

- $23 \%$ are undernourished.

- $41 \%$ live on less than $\$ 1.25$ a day. 
Challenges are not unique to sub-Saharan Africa, as the United Nations (2015b) report makes clear:

- $44 \%$ of those living in Oceania still lack access to an improved water source.

- $53 \%$ of the population of Southern Asia do not use an improved sanitation facility.

- $64 \%$ of women in Southern Asia do not receive the minimum advised antenatal visits during pregnancy, and only $52 \%$ of all births are attended by skilled health personnel.

- The proportion of undernourished people in the Caribbean region still stands at $20 \%$, compared to less than $5 \%$ in neighbouring Latin America.

- There is a projected decrease in the literacy rate of boys in Oceania between 1990 and 2015, although the region has made significant progress in increasing the literacy rate of girls.

These percentages demonstrate some of the significant challenges that remain around the world, as well as highlighting the uneven nature of development progress in recent decades. Stated percentages equate to thousands of communities and hundreds of millions of people all lacking access to basic needs. Toilet facilities, clean water supplies, reliable food sources, safe shelters and suitable infrastructure, as well as access to education, healthcare and energy sources may be limited or absent altogether. These challenges can result in communities being particularly vulnerable to climate change and natural hazards (e.g., earthquakes, volcanic eruptions, landslides and floods). Furthermore, there are an increasing number of people displaced as a result of conflict, violence, and human rights violations, jeopardising the recent progress that has been made in development. As of 2014, approximately 60 million people were displaced, due to conflicts in countries such as Somalia, Iraq, Syria, Nigeria, South Sudan, and Ukraine (United Nations, 2015b). This represents an increase of approximately 15 million people over just two years.

To fully comprehend current development challenges, the lack of access to resources in some parts of the world needs to be contrasted with overconsumption in other parts of the world. The Global Footprint Network (2016) estimates that each year humans currently use the equivalent of 1.5 times the resources that can be regenerated in a given year (e.g., cropland, fish stocks, and forest). This consumption is not distributed uniformly across all nations, with some countries likely to be using significantly more of these resources than others. An increasing demand for other materials, including minerals, is being driven by population growth and a growing middle class (Lambert et al., 2013), but also by overconsumption in many places.

It is set against this context that the SDGs have been agreed, aiming to eliminate the remaining extreme poverty that exists, while simultaneously facilitating a sustained and inclusive programme for economic growth, social development, and environmental protection. The global consensus, finance, and policy changes that are necessary to meet the SDG targets are significant and ambitious. The progress made over the past 15-25 years, however, offers hope that they are achievable. Success is dependent on a diverse array of factors, not least the effective engagement of multiple communities of practice and fruitful interactions between them. A failure, therefore, of the geology community to engage effectively with the SDG process could hinder the overall successful achievement of the SDGs. Consequently, it is important that geologists (i) examine what the SDGs are and how geological science informs their achievement, and (ii) engage in discussions that consider what changes should be made to ensure that geology education, research and practice best supports sustainable development and the fight against global poverty.

\section{Sustainable Development Goals}

The SDGs consist of 17 goals and 169 targets, covering topics as diverse as food security, education, gender equality, energy supply and sustainable consumption and production patterns (United Nations, 2015a). As noted previously, the SDGs aim to eradicate global poverty, end unsustainable consumption patterns and facilitate sustained and inclusive economic growth, social development and environmental protection (United Nations, 2015a), operating from 2015 to 2030. The diversity of the goals and their stated aims mean that they have direct relevance to all nations, at all stages of economic and social development. Countries as diverse as Burkina Faso, the United Kingdom, India, Germany, Tanzania, the Solomon Islands, and Guatemala have a responsibility to engage with the SDGs and make progress towards the SDG targets. In this context, geologists around the world, of all nationalities and specialisms, should be willing and equipped to make their contribution to supporting and facilitating sustainable development.

\section{Geology and SDGs matrix}

The SDGs have been simplified into 17 short phrases by Global Goals (2016) to simplify their communication. In Figure 2 the vertical axis of a matrix presents these identifying phrases, together with the official wording of each SDG. On the horizontal axis 11 key aspects of geology are noted. Though not exhaustive, this list represents a wide array of geology sub-disciplines, areas of application, skills and outreach. The 11 key aspects of geology are grouped under two headings. Eight of the 11 key aspects of geology fall into the broad grouping of 'Earth Materials, Processes and Management'. These eight aspects are: agrogeology, climate change, energy, engineering geology, geohazards, geoheritage and geotourism, hydrogeology and contaminant geology, and mineral and rock resources. Each of these eight aspects of geological science are fully described in Table 1, with examples of the professional roles that may engage in these areas of application. Table 1 is designed to support the interpretation of Figure 2 by those in policy and practitioner communities. Three further aspects included within Figure 2 are grouped as 'Skills and Practice', which relates to the sharing of and/or adaptations to geological methods to serve sustainable development. These three aspects are: education, capacity building and a broad miscellaneous category. Footnotes are included to explain the specific or general role of geologists referred to within this miscellaneous category.

Shading of matrix cells within Figure 2 indicates that achieving the given SDG (vertical axis) requires an understanding of the highlighted aspect of geology (horizontal axis). For example, row 9 shows SDG 9 (infrastructure and innovation) and has the cell corresponding to engineering geology shaded in as engineering geologists are involved in the development of sustainable, resilient infrastructure. While the 
Table 1. Descriptions of the eight key aspects of geological science identified within the 'Earth Materials, Processes and Management' section of Figure 2

\begin{tabular}{|c|c|c|}
\hline $\begin{array}{c}\text { Geological Sciences (Earth Materials, } \\
\text { Processes and Management) }{ }^{(1)}\end{array}$ & Description $^{(2)}$ & Example Job Titles $^{(3)}$ \\
\hline Agrogeology & $\begin{array}{l}\text { The use of rock and mineral resources to improve agriculture } \\
\text { through improving soil fertility and water retention, and reducing } \\
\text { soil erosion. }\end{array}$ & Environmental Consultant; Geochemist. \\
\hline Climate Change & $\begin{array}{l}\text { Using the geological record to understand past changes to the cli- } \\
\text { mate and applying this knowledge to understand how the climate } \\
\text { may change in the future. }\end{array}$ & $\begin{array}{l}\text { Climate Scientist; Field Geologist; } \\
\text { Geochemist. }\end{array}$ \\
\hline Energy & $\begin{array}{l}\text { Identifying and advising on potential energy sources (e.g., geo- } \\
\text { thermal, hydrocarbons) and raw materials required for energy } \\
\text { supply and infrastructure (e.g., uranium ore for nuclear energy, } \\
\text { iron ore for wind turbines, cadmium for photovoltaic cells). Con- } \\
\text { tributing to the safe extraction and storage of resources and the } \\
\text { development of energy infrastructure. }\end{array}$ & $\begin{array}{l}\text { Engineering Geologist, Geochemist; } \\
\text { Geophysicist; Hydrogeologist; Mining } \\
\text { Geologist, Petroleum Geologist; Seis- } \\
\text { mic Interpreter. }\end{array}$ \\
\hline Engineering Geology & $\begin{array}{l}\text { The application of geological sciences to engineering, supporting } \\
\text { the design and construction of infrastructure at all scales (e.g., } \\
\text { dams, roads, tunnels, airstrips, ports, pipelines, shelters). }\end{array}$ & $\begin{array}{l}\text { Engineering Geologist; Geomorpholo- } \\
\text { gist. }\end{array}$ \\
\hline Geohazards & $\begin{array}{l}\text { Understanding the physical science underlying the generation of } \\
\text { natural hazards, including landslides, earthquakes, tsunamis and } \\
\text { volcanic eruptions. Assessing exposure through producing haz- } \\
\text { ard maps. Supporting efforts to reduce vulnerability through geo- } \\
\text { education and capacity building initiatives. }\end{array}$ & $\begin{array}{l}\text { Engineering Geologist; Sedimentolo- } \\
\text { gist; Seismologist; Volcanologist. }\end{array}$ \\
\hline Geoheritage and Geotourism & $\begin{array}{l}\text { Using geology and landscapes within tourism, aiding the conser- } \\
\text { vation of geodiversity and building a greater understanding and } \\
\text { appreciation of the geological sciences by tourists and those com- } \\
\text { munities living and working around geological features. }\end{array}$ & $\begin{array}{l}\text { Geoscience Communicator; Geosci- } \\
\text { ence Educator. }\end{array}$ \\
\hline $\begin{array}{c}\text { Hydrogeology and Contaminant } \\
\text { Geology }\end{array}$ & $\begin{array}{l}\text { Understanding and sustainably managing groundwater resources. } \\
\text { Using geological sciences to assess and monitor and remediate } \\
\text { contamination, including understanding the origin, transportation } \\
\text { and fate of contaminants. }\end{array}$ & $\begin{array}{l}\text { Contaminant Hydrogeologist; Envi- } \\
\text { ronmental Consultant; Geochemist; } \\
\text { Geophysicist; Hydrogeologist. }\end{array}$ \\
\hline Minerals and Rock Materials & $\begin{array}{l}\text { The use of geological sciences to identify and develop mineral } \\
\text { and rock resources, for a variety of uses (e.g., ores for metal pro- } \\
\text { duction, limestone for building stone or glass). }\end{array}$ & $\begin{array}{l}\text { Economic Geologist; Exploration } \\
\text { Geologist; Geochemist; Hydrogeolo- } \\
\text { gist; Mineral Commodity Geologist. }\end{array}$ \\
\hline
\end{tabular}

${ }^{(1)}$ Key aspects (areas of geological science application) taken from Figure 2.

${ }^{(2)}$ A description of the eight key aspects, used within the grouping 'Earth Materials, Processes and Management' in Figure 2.

${ }^{(3)}$ Selected examples of the professional positions that may be involved in these areas of application, recognising that there is crucial role for other professional positions (e.g., survey geologists and professional researchers) in all these roles.

importance of education and capacity building in all the SDGs should be stressed, there are particular SDGs (shaded in Fig. 2) for which there is a specified role for education and capacity building noted within the SDG targets and means of implementation.

In order to maximise visual clarity, this summary matrix loses some of the detail noted in the 169 targets and means of implementation. The matrix in Figure 2 needs to be studied alongside Table 1 and the detailed narrative of each SDG to best understand how any given aspect of geology supports the stated SDG. For example, in Figure 2, row 6 shows Goal 6; ensure availability and sustainable management of water and sanitation for all. The cell corresponding to 'hydrogeology and contaminant geology' is shaded as an understanding of groundwater resources is essential to the provision and sustainable management of clean water for all. When examining the detail of this goal (United Nations, 2015a), the role of hydrogeologists working across all sectors is even more apparent, working to ensure sustainable groundwater withdrawals, the protection of aquifers and improvements to water quality by reducing pollution.

It is evident from the synthesis presented in Figure 2 that many of the SDGs rely on the input of geologists at one or more stages of their implementation and success:

- In 12 of 17 of the goals (71\%), one or more aspects from the 'Earth
Materials, Processes and Management' group are shaded within the matrix.

- In 10 of 17 of the goals (59\%), one or more aspects from the 'Skills and Practice' group are shaded within the matrix.

- In 17 of 17 of the goals (100\%) one or more aspects from the 'Earth Materials, Processes and Management' group or 'Skills and Practice' group are shaded within the matrix.

The type of contribution required differs from goal to goal, with some requiring an input unique to the geology community and others requiring a promotion of values or changes in working practices across all sectors, including the geosciences. For example, geology is a foundational 'knowledge source' when considering clean water and sanitation (Goal 6), where current knowledge, future research and some of the practical skills required to meet this goal are unique to the geology community. In other examples, geology is one of many communities that could seek to actively promote the values that the goal seeks to convey. The latter are commonly represented in Figure 2 with the matrix cell shaded in the final column, representing a miscellaneous aspect of geology. When considering gender equality (Goal 5), for example, the geological community must take responsibility for ensuring that all opportunities presented within geology-based academia, industry and public sectors are equally accessible to all, irrespective 


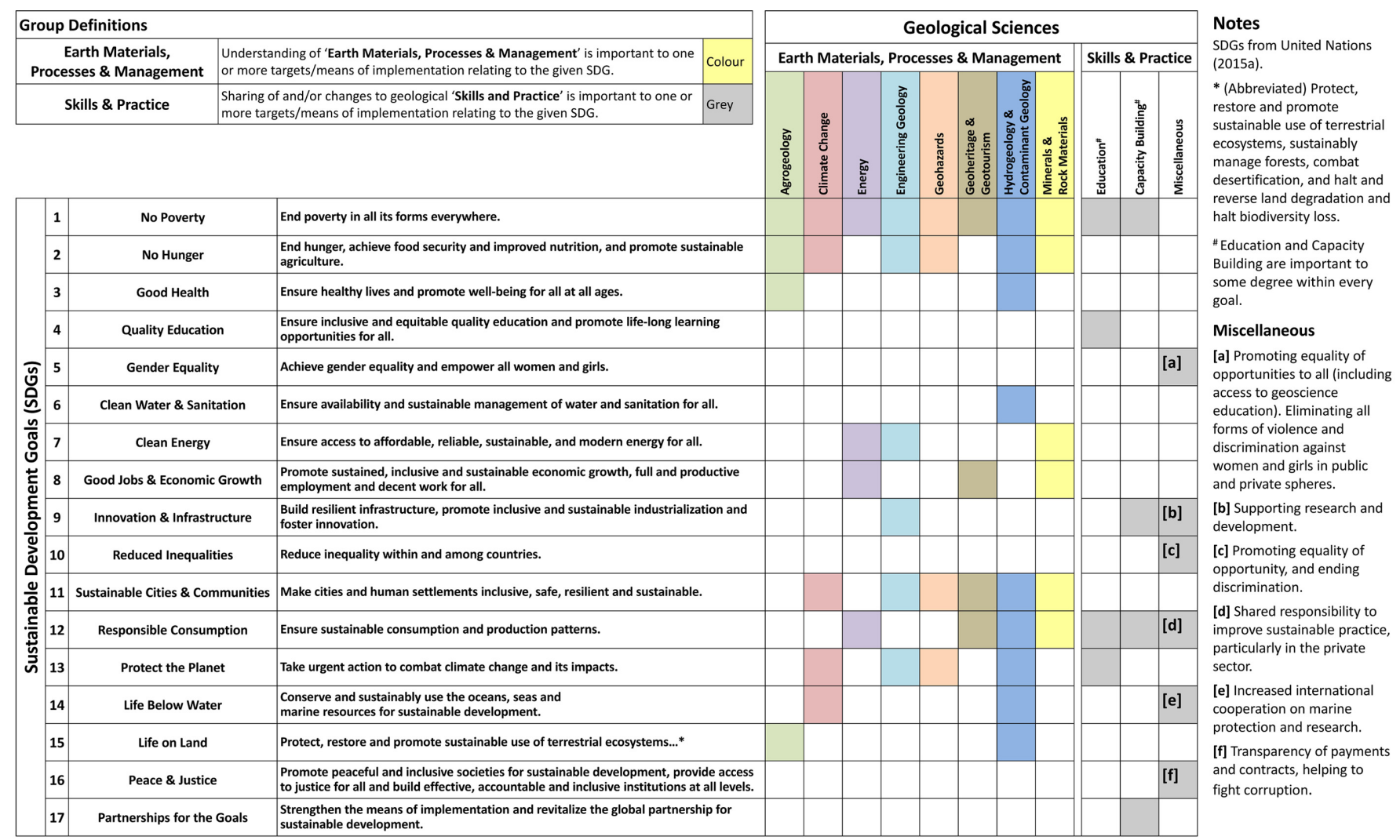

Figure 2. Geology and the Sustainable Development Goals: A matrix to visualise the role of geologists in helping to achieve the internationallyagreed Sustainable Development Goals. Descriptions of categories within 'Earth Materials, Processes and Management' can be found in Table 1.

of gender. For example, this may require greater efforts to recruit and retain female students to the subject, recognising that in some parts of the world the number of women in the science is far from ideal. Goal 5 includes eliminating all forms of violence and discrimination against women and girls in public and private spheres, including the elimination of trafficking and sexual and other types of exploitation (United Nations, 2015a). A responsibility to address this goal rests with all sectors and industries, including the sectors in which geologists operate. The use of trafficked individuals, for example, is a challenge within some aspects of agriculture and mining (Wheaton et al., 2010).

The presented analysis of the SDGs (Fig. 2) is likely to give a conservative assessment of the role of geoscience in the SDGs, with geoscience interventions to support one goal (e.g., clean water) supporting efforts to achieve other goals (e.g., gender equality). Nevertheless, Figure 2 demonstrates the need for input from geologists, in a variety of forms, in all of the goals. Alternative classifications of areas of geological science, or methodologies for analysing the role of geology in the SDGs, may produce slightly different matrices. Each is likely to demonstrate the need for a diverse input from the geology community. This required and diverse input it not unique to geology; similar analyses by engineers, lawyers, health professionals, spatial planners, human geographers and many other professions would almost certainly identify similar results. Complementary analyses would facilitate a better understanding of how each discipline can contribute to sustainable development, and how we can partner to have greater impact.

Understanding the specific inputs into the SDGs required from geologists can inform the geology sector, but also a range of other stakeholders. The synthesis presented within this paper can be used to help inform development practitioners, policy makers, administrators and other groups of the role of geological knowledge in addressing societal and sustainability challenges.

\section{Initiating a sector-wide discussion}

Recognising the role of geologists in sustainable development obligates the geology community to carefully evaluate our existing structures, in order to ensure our contributions are most effective. The sector has a responsibility to examine whether changes are necessary to our education programmes, ongoing professional development and training, research agendas, industry practice, and engagement with non-governmental, governmental and intergovernmental organisations.

Here, three themes are discussed that could help improve engagement by the geology community in sustainable development. This list is not exhaustive, for example it does not discuss the need for full engagement by the diversity of geoscience industries. Leadership is required by the private sector, with their support crucial for effective policies, processes and stakeholder engagement (Sachs, 2012). This section 'Initiating a sector-wide discussion' intends to provoke and contribute to much needed debate within the wider geological science community on topics such as (i) what role geology can play in the SDGs, (ii) how this is done most effectively, and (iii) what needs to change in our current structures to facilitate this effective engagement? At a recent annual conference of Geology for Global Develop- 
ment ( $30^{\text {th }}$ October 2015 , London, UK), approximately 120 young geologists were invited to share their thoughts on how the geology sector could adapt to support the SDGs. Similar discussions could take place at many levels, including within student-led geology groups, individual university departments, national geological science committees, geological surveys, professional and learned institutes, industry boardrooms, and regional and international geosciences unions. In the context of this article, the focus is on the need to develop supporting skills in education, improve transnational collaborations in research, and ensure and encourage respectful capacity building initiatives by groups such as learned and professional societies and geoscience unions.

\section{Development of supporting skills in education}

Effectively applying an understanding of geology to international poverty-fighting projects requires more than just a competent understanding of technical geology. While this technical understanding is one essential foundation, so is a thorough understanding of locationspecific social, cultural, economic, ethical and environmental factors (Amadei, 2004). Without these aspects of contextual understanding, it is very difficult to improve sustainability, have maximum impact and interact with communities in a socially responsible manner. Assessing this context, and using this information to greatest effect, requires skills such as cross-cultural and cross-disciplinary communication, diplomacy, and community engagement (Liverman, 2008; Robb, 2013; Lubchenco et al., 2015; Gill, 2016). It also necessitates the integration of a wide array of social science research techniques into technical geology investigations. These skills, integrated with knowledge of community vulnerability, and national and international development policy, give a greater chance of safe, sustainable and successful engagement (Gill, 2016). The importance of developing a location-specific contextual understanding is often not reflected in the training and professional development given to young geologists, with few opportunities to develop the skills outlined in this section. Investing early in the nurturing of these skills, however, can help shape long-term attitudes towards and proficiency in interdisciplinary and overseas development work. As graduates move into the workplace, a workforce equipped with strong communication and diplomatic skills, allowing the co-production of innovative solutions would be a great asset to the application of geology to sustainable development (Gill, 2016).

\section{Improving transnational collaborations in research}

The nature of geology means that it is commonplace to find researchers from one country working on problems in another country. This often includes researchers or research groups in established centres of scientific excellence working in low and lower-middle income countries. Overseas research often requires significant goodwill and support of host-country scientists and technicians, from universities and geological surveys. Such interactions, if done well, provide a valuable opportunity for genuine knowledge exchange. Host-country scientists and institutions offer valuable insights into location-specific context (e.g., cultural, social and scientific context). Visiting scien- tists from established centres of scientific excellence can bring expertise and supply training in fieldwork and data collection, access to data and reports derived from the fieldwork, and possible collaborations in authorship of publications. Sadly, these examples of positive interactions are by no means normal practice. Visiting scientists sometimes fail to send data, reports and publications relating to collaborative work, or fail to engage host-country scientists in the writing and publishing of articles derived from collected data (Gill, 2015). This lack of best practice in transnational collaboration deprives both parties of important benefits and learning opportunities. Genuine transnational collaborations, with co-authored publications and full data sharing would allow host-country scientists to grow in their own research, analytical and dissemination skills (Hewitson, 2015). Such collaborations provide the host-country with a richer scientific capacity to draw upon, and offer the international geology community access to the insights and intellect of a broader sub-set of the community, helping to advance our collective understanding (Hewitson, 2015).

\section{Ensuring respectful capacity building initiatives}

In Figure 2 four SDGs were identified where some element of capacity building by geologists would help achieve the respective SDGs and is discussed within relevant SDG targets. In addition to being of general importance for Goal 1 (end poverty), scientific capacity building was noted as a specific target or means of implementation for Goal 9, building resilient infrastructure; Goal 12, ensuring sustainable consumption and production patterns and Goal 17, revitalising global partnerships. Furthermore, peer-to-peer capacity building (or mentoring) will be important in achieving sustainable solutions to many of the other SDGs. If done well, effective capacity building and knowledge exchange can offer vital skills, training and understanding in both technical geology and associated business skills (Stephenson and Penn, 2005). This is dependent, however, on a willingness to invest time and resources in ensuring good, sustainable practice. Hewitson (2015) posed two questions for capacity building initiatives: what type of capacity needs to be built and why? Hewitson (2015) progressed to argue that capacity building shouldn't be based on assumptions made from a distance about the needs of a community, where that community could be a village, a geological survey, a university department or a government ministry. It is important that the geology community gives these comments due attention. Capacity building programmes will likely have maximum effect if they involve meaningful consultation, with all relevant groups represented, working together as equal partners. Meaningful consultation will demand many of the supporting skills introduced previously, for example cross-cultural communication, public engagement, diplomacy and social science research skills. A capacity building project that is designed in this manner will require more background research, take longer to develop and likely require a greater amount of initial financial investment in the scoping stage. If meaningful consultation and respectful partnerships are missing, however, the project is unlikely to truly understand what capacity is needed, why this is important, and how this can be best achieved in a sustainable manner. Sustainable development requires capacity building initiatives that are mature and respectful, adopting a bottom-up approach. 


\section{Conclusions}

This article has reviewed the role of geology in achieving the Sustainable Development Goals (SDGs), identifying many themes where the geology community can help eradicate poverty and support sustainable development. Despite widespread progress in tackling extreme poverty through the Millennium Development Goals, many aspects of poverty still persist, alongside unsustainable consumption patterns. While noting the current positive engagement in sustainable development by some geologists and geology groups, this article emphasises that future engagement must come from the broadest spectrum of the geology community. Across agrogeology, climate change, energy, engineering geology, geohazards, geoheritage and geotourism, hydrogeology and contaminant geology, mineral and rock resources, geoeducation, geological capacity building and other broad miscellaneous areas of professional values, geologists can support the 17 internationally-agreed SDGs. Effective engagement should draw upon geologists within civil society, the public sector and private sector.

In the context of achieving the SDGs, this article has highlighted possible changes to education, research practice, and the design of capacity strengthening programmes. Discussions on these themes, and many others, should now be encouraged at all levels, to assess what changes are required to support engagement by the geology community with the SDGs. Important themes for discussion are likely to arise as individuals and groups begin their engagement with the SDGs. Online and offline spaces for these discussions, including at scientific conferences and through professional organisations, should be created to assist in mobilising geologists.

This synthesis and associated visualisation framework seeks to do the following: (i) mobilise and motivate the broader geology community to engage in the Sustainable Development Goals, allowing those working on specific aspects of geology to consider their work in the context of sustainable development; and (ii) demonstrate the role of geology within sustainable development to other relevant disciplines, policy-makers and development practitioners.

\section{Acknowledgements}

I wish to thank Dr Brian Marker OBE and Dr Greg Wessel for their helpful reviews, and Nic Bilham and Florence Bullough for their insightful comments in the preparation of this manuscript.

\section{References}

AGID, 2016, About AGID: http://www.bgs.ac.uk/agid/ (accessed January 2016).

Amadei, B., 2004, Engineering for the developing world: Bridge-Washington-National Academy of Engineering, v.34, pp. 24-31.

BGS, 2016, Past Projects, https://www.bgs.ac.uk/research/international/ fullResults.cfm?action=listAll (accessed January 2016).

Cordani, U.G., 2000, The role of the earth sciences in a sustainable world: Episodes, v.23, no.3, pp. 155-162.

Gill, J.C., 2012, Geology for Global Development: Geoscientist, v.22, no.7, pp. 18-20.
Gill, J.C., 2015, Commentary - 'Globalize Geoscience' and International Capacity Strengthening: http://blogs.egu.eu/network/gfgd/2015/07/13/commentary-globalize-geoscience-and-international-capacity-strengthening/ (accessed January 2016).

Gill, J.C., 2016, Building good foundations: Skills for effective engagement in international development, in Wessel, G.R., and Greenberg, J.K., eds., Geoscience for the Public Good and Global Development: Toward a Sustainable Future. Geological Society of America Special Paper, v.520, pp. 1-8. doi:10.1130/2016.2520(01)

Global Footprint Network, 2016, World footprint: Do we fit on the planet? http://www.footprintnetwork.org/en/index.php/GFN/page/world_footprint/ (accessed January 2016).

Global Goals, 2016, The Global Goals: http://www.globalgoals.org/ (accessed January 2016).

Hewitson, B., 2015, To build capacity, build confidence: Nature Geoscience, v.8, no.7, pp. 497-499.

Lambert, I., Durrheim, R., Godoy, M., Kota, M., Leahy, P., Ludden, J., Nickless, E., Oberhaensli, R., Anjian, W., and Williams, N., 2013, Resourcing future generations: A proposed new IUGS initiative: Episodes, v.36, no.2, pp. 82-86.

Liverman, D.G.E., 2008, Environmental geoscience; communication challenges, in Liverman, D., Pereira, C.P., and Marker, B., eds., Communicating environmental geoscience. Geological Society of London, Special Publications, v.305, no.1, pp. 197-209.

Lubchenco, J., Barner, A.K., Cerny-Chipman, E.B., and Reimer, J.N., 2015, Sustainability rooted in science: Nature Geoscience, v.8, no.7, pp. 741-745.

Millennium Project, 2006, Millennium Development Goals: http://www. unmillenniumproject.org/goals/index.htm (accessed January 2016).

Mora, G., 2013, The need for geologists in sustainable development: GSA Today, v.23, no.12, pp. 36-37.

Robb, J., 2013, A call for increased public engagement in geology higher education: Geology Today, v.29, no.2, pp. 63-67.

Sachs, J.D., 2012, From millennium development goals to sustainable development goals: The Lancet, v.379, no.9832, pp. 2206-2211.

Stephenson, M.H., and Penn, I.E., 2005, Capacity building of developing country public sector institutions in the natural resource sector: Geological Society of London, Special Publications, v.250, no.1, pp. 185-194.

Stow, D.A.V., and Laming, D.J.C., (eds.), 1991, Geoscience in development: The Geosciences in International Development AGID Report Series, v.14, 327 p.

United Nations, 2015a, Transforming Our World: The 2030 Agenda for Sustainable Development: United Nations, Geneva, $35 \mathrm{p}$.

United Nations, 2015b, The Millennium Development Goals: Report, United Nations, Geneva, $75 \mathrm{p}$.

Wheaton, E.M., Schauer, E.J., and Galli, T.V., 2010, Economics of human trafficking: International Migration, v.48, no.4, pp. 114-41.

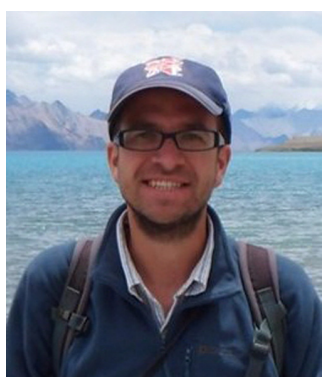

Joel C. Gill is the Founder/Director of Geology for Global Development (www.gfgd.org). This not-for-profit organisation works to mobilise and equip the geology community to engage in international development. Joel has a PhD in geography, characterising natural hazard interactions to improve multi-hazard approaches. $\mathrm{He}$ is currently based at the British Geological Survey, supporting their overseas development programme of research and engagement. Joel has worked in Chile, China, Guatemala, India and Tanzania, advising on water, geohazard, geoeducation and sustainable development projects. He is a Fellow of the Geological Society of London and an Associate Fellow of the Royal Commonwealth Society. 